\title{
A Soteriological Response to the Congolese Pastors' Engagement with Children Accused of Being Witches
}

\author{
Collium Banda
}

\section{Introduction}

The findings in the study Christian Pastors and (Alleged) Child Witches in Kinshasa, DRC, by Robert J. Priest, Abel Ngolo, and Timothy Stabell (2020), highlight the vulnerability of African children, many of them orphans and step-children, to accusations of witchcraft. However, a fundamental problem highlighted in the study is a poor Christian doctrine of salvation in an African context where an enchanted worldview reigns supremely. Therefore, my response to the study by Priest et al. will dwell on the soteriological problems arising from pastors' endorsement of accusations of witchcraft made against the children. I dwell on the issues of salvation because I believe that our soteriological framework will shape our response and attitude towards the children accused of witchcraft and how we engage with the reality called witchcraft.

The question that emerges from reading the study is: Soteriologically, how can the endorsement of witchcraft allegations against children witches by some charismatic/Pentecostal (revivalist churches) pastors be evaluated? In other words, in terms of Christian salvation, what does it mean for the concerned pastors to endorse the allegations of witchcraft against children brought before them and implement an array of deliverance mechanisms such as forcing the accused children to fast and inducing them to vomit? This will be the focus of my response to the above named study.

\section{The Christian Influence on the Belief in Child Witches in Southern Africa}

It is important to first note how Christianity continues to influence and shape the belief in child witches in Africa. I come from Zimbabwe, in centralsouthern Africa, where common victims of witchcraft accusations are usually elderly people, especially elderly women. In traditional Zimbabwean communities, children accused of witchcraft are often thought to have inherited it from an ancestor who was/is a witch. There is a strong belief that witchcraft is hereditary (Parrinder 1976, 124; Bozongwana 1983, 40). The Ndebele people say the child of a snake is a snake, umntwana wenyoka yinyoka, while the Shona people say witchcraft that exists within a family ancestry can never be eradicated, uroyi hwedzinza hauperi, to indicate that children from a line of ancestry that practiced witchcraft will inherit witchcraft. There is also a belief that a child may pick the practice up from a stranger who discards the spirit of witchcraft by passing it to the concerned child, or the child may be a victim of witchcraft by being bewitched by a spirit of witchcraft. Consequently, traditional Zimbabwean communities strongly warn their children against picking up lost items, especially objects found on crossroads (that is where people discard their unwanted spirits), touching or eating chickens and goats found wandering in bushes (that is how people send away their evil spirits), receiving food and things from strangers (they may be passing their bad spirits away) and indiscriminately shaking hands with strangers (they may be passing their evil spirits to you). Traditionally, in Zimbabwe, elderly people are much more likely to be accused of witcheraft than children.

However, with the rise of the African neoPentecostalism, a Christianized version of accusation of witchcraft against children is gaining momentum in Zimbabwe by accusing people of practising Satanism. News reports have cited several cases of allegations of school children practicing Satanism (Chaya 2015; The Chronicle 2017). Journalists from Zimbabwe's daily newspaper, NewsDay, Jairos Saunyama and Shingirai Vambe (2018) reported that in one school a student allegedly initiated several classmates into Satanism by giving them money and gifts. In plain terms, the student was accused of bewitching fellow classmates. Since Satanism is basically a Christian construct, the increasing number of school children accused of 
Satanism is a modern Christianized trend of calling children witches. The increasing incidents of accusations of Satanism show the influential role of Christianity in both shaping people's ideas about witchcraft and also giving momentum to the belief in children witches. While conducting research on the fear of witchcraft among Christians (Banda and Masengwe 2018), we encountered a father who reported that his daughter, studying at a Christian secondary school, had expressed intense fears of fellow students who mysteriously 'stole' other students' intelligence causing them to fail their exams.

However, in Zimbabwe the momentum of belief in witchcraft has also come from itinerant witch hunters, called Tsikamutanda, a Shona word for 'step on the log' describing their method of determining if one is a witch. It is difficult to describe the Tsikamutanda because some appear like traditional healers while others operate like prophets from African Independent Churches. Against the Witchcraft Suppression Act, the Tsikamutanda roam around Zimbabwean villages cleansing the land of witches by exorcising the spirit of witchcraft from people accused of practicing it and destroying their tools of trade. Although the law forbids labelling any person a witch, the authorities have largely failed to decisively stamp out the activities of the Tsikamutanda, partly because some village authorities and ordinary people believe in the genuineness of the witch-hunts. It can be argued that African neoPentecostal prophets by their deliverance services also practice a Christianized version of witch-hunting and cleansing. The doctrine of inherited curses, in which witchcraft is included as an inherited curse, and the prevalence of deliverance services in African neoPentecostal churches and the witch-hunting and cleansing ceremonies of the Tsikamutanda are intensely opposed religious systems that work together to give momentum to the belief in witchcraft.

\section{The Expression of Christian Salvation in Primitivistic Terms}

In terms of Christian salvation, the endorsement of the belief in child-witchcraft as reflected in the response of the pastors in the study by Priest et al. challenges the essence of Christian salvation and how God saves people. While discussions may legitimately centre on debating the genuineness of the accusations of witchcraft against children, the question that still remains is: soteriologically, does requiring children to fast, confess that they are witches, making them drink a special potion of medicine, inducing them to vomit, shaving their heads, making them pass through fire or causing them to bleed, constitute a biblically informed way of liberating people from spiritual bondage? Therefore, a fundamental challenge with the African
neo-Pentecostal response to witchcraft is an unbiblical soteriological plan that is more informed by African Traditional Religions (ATR) than by Christ and his work of salvation on the cross.

A critical challenge is the endorsement and promotion of a primitivistic view of Christian salvation with salvation projected as liberation from evil spirits. In addition to undermining the universal sinfulness of humanity (Rom 3:23), a primitivistic view of salvation fails to understand that Christian salvation is primarily entering into a saving personal relationship with God. Ngong $(2009,14)$ criticises the growth of African neoPentecostalism for promoting a 'worldview that inordinately stresses on the effect of spiritual beings on daily life and the view of daily life as a struggle for power'. In the primitivistic view of Christian salvation, the predominant notion of sin is not humanity's broken relationship with God (Rom 3:23), but humanity's possession by evil powers. This primitivistic view of salvation often stops with preoccupation with gory visions of the power of demons while losing sight of the essence of the glorious biblical images that describe the state of the Christian believer. One has to ask how requiring children to fast, confess that they are witches, making them drink a special potion of medicine, inducing them to vomit, shaving their heads, making them pass through fire or causing them to bleed tallies up with the biblical view of salvation as being born again, being freed from all condemnation (Rom 8:1); being a temple of the Holy Spirit (1 Cor 6:19), being adopted as God's child (Rom 8:14-17), being rescued from the dominion of darkness and being brought into the kingdom of Christ (Col 1:13) and having one's life hidden with Christ in God ( $\mathrm{Col} 3: 3)$. A view of salvation that predominantly views salvation in notions of freedom from demons, instead of salvation as the freedom from the power of sin and entering into a personal relationship with God is fertile ground for dangerous superstitious beliefs of child witches.

\section{The Promotion of an Impersonalised View of God}

The primitivistic view of salvation that condones accusations of witchcraft against children further promotes an impersonalised view of God. This leads to a utilitarian view of religion instead of personal relational religion with God. The pastors' response to the problem of witchcraft shows an impersonalised view of God because solutions to the problem of witchcraft are not searched for in the saving relationship with God but in a cocktail of impersonal measures such as the above listed procedures. Instead of leading a troubled person into a relationship with God, African neoPentecostals use impersonal religious methods that are used in ATR for relief from the spirits of witchcraft. 
ATR are religions based on an impersonal power (Beyers 2010, 2). By impersonal power is meant that even though there is a firm belief in God (Mbiti 1990, 29), with personal attributes applied to him (Mbiti 1990, 33), yet he is largely viewed in impersonal terms because he is considered detached from the worldly affairs, having delegated them to a hierarchy of spiritual beings. In ATR access to God is through ancestral spirits, and various magical and mystical objects are used to draw from God the power needed for people's daily existence. Scholars use different names to describe the impersonal power in ATR such as Placides Tempels' (Magesa 1997, 50) notion of 'forces of life' or 'vital forces'. Turaki $(1999,182)$ highlights numerous names such as mana, life force, vital force, life essence and dynamism, high mysterious powers, and mysterium tremendum. At the centre of the pervasive religiosity in Africa is the quest to take hold of the impersonal power and control it for one's benefit (Mbiti 1990; Okorocha 1994, 72; Magesa 1997, 33). In ATR religiosity and magical charms and religious practices such as fasting, and drinking special potions of medicines are often a means of tapping into the personal power. This means that religiosity has a utilitarian function; its duty is to keep one connected to the impersonal vital force in order to keep evil spirits such as witchcraft away from an individual.

Traditional Africans recognise that witchcraft can be either voluntarily or involuntarily acquired; therefore, Africans diligently protect themselves from being a victim or a practitioner (Banda and Masengwe 2018, 3). They safeguard themselves by wearing magical instruments like amulets around necks, arms, legs and waists, and they make incisions on their bodies through which powerful medicines are deposited into their blood to protect them from, and to counter, the effects of witchcraft, which Nyathi $(2001,21)$ calls "missilerepellents”. Furthermore, traditional Africans protect themselves by endearing themselves to their ancestors through appeasing them and performing various religious duties towards them (Banda and Masengwe 2018, 3).

It is contended that the uncritical adoption and incorporation of the ATR worldview and impersonal methods of fighting the spirit of witchcraft blinds Christians from critically engaging, evaluating and questioning the objective genuineness of the belief in witchcraft. The impersonalisation of God by requiring children to undergo the above listed procedures kills a meaningful analysis of the reality of witchcraft. Dealing with accusations of witchcraft against children from God's personal nature may lead one to ask: if Christ projected such a positive view of children as an example to be followed by those seeking his kingdom (Mk 10:1316), how can it be true that children can be witches? Furthermore, a response to witchcraft informed by
God's personal nature may lead Christians to realise that God's solution to the problem of sin and human problems such as witchcraft is not a cocktail of dehumanising and degrading violent activities against children. Rather, God's solution to our problem is his very redemptive personal presence (Matt 28:20). We find spiritual security by personally relating with God, not magically manipulating him. It is important to note that in Ephesians 6:10-20 the armour of God that Christians are commanded to put on to fight the devil is ultimately God himself and not spiritual gadgets. The belt of truth, the breast of righteousness, the gospel of peace, the shield of faith, the sword of the Spirit and praying in the Spirit are all aspects of personally relating to God.

\section{Conclusion}

This response to Christian Pastors and (Alleged) Child Witches in Kinshasa, DRC, by Robert J. Priest, Abel Ngolo, and Timothy Stabell, attempted to answer the question: Soteriologically, how can the endorsement of witchcraft allegations against children witches by some charismatic/Pentecostal (revivalist churches) pastors be evaluated? The response highlighted that a serious problem in the pastors' engagement with children accused of witchcraft is the impersonalisation of God which leads to superstitious solutions. The concerned pastors are challenged to view accusations of witchcraft against children from the perspective of God as a personal Saviour. God is personally interested in all the children accused of witchcraft.

\section{References}

Banda, Collium, \& Masengwe, Gift. 2018. Overcoming Fear? A Search for an Empowering Theological Response to the Fear of Witchcraft among Urban Zimbabwean Christians. Verbum et Ecclesia 39 (1):110. https://doi.org/a1837. https://doi.org/ 10.4102/ve.v39i1.1837.

Beyers, Jaco. 2010. What Is Religion? An African Understanding. HTS Teologiese Studies / Theological Studies 66 (1):8. https://doi.org/10.4102/hts.v66i1.341.

Bozongwana, Wallace. 1983. Ndebele Religion and Customs. Gweru: Mambo.

Chaya, Vasco. 2015. Satanism Scare Hits Harare School. DailyNews Live. 29 September 2015. https://www.dailynews.co.zw/articles/2015/09/29/satanis m-scare-hits-harare-school

Magesa, Laurenti. 1997. African Religion: The Moral Traditions of Abundant Life. Maryknoll. NY: Orbis. 
Mbiti, John.S. 1990. African Religions \& Philosophy. Second Edition. Gaborone: Heinemann Educational Botswana.

Ngong, David. T. 2009. Salvation and Materialism in African Theology. Studies in World Christianity. 15(1):1-21.

https://doi.org/10.3366/E135499010900032X.

Nyathi, Phathisa. 2001. Traditional Ceremonies of Amandebele. Gweru: Mambo.

Parrinder, Geoffrey. 1976. African Tradtional Religion. Connecticut: Greenwood.

Priest, Robert J., Abel Ngolo and Timothy Stabell. 2020. Christian Pastors and Alleged Child Witches in Kinshasa, DRC. On Knowing Humanity Journal 4(1):1-51.

Saunyama, Jairos, \& Vambe, Shingai. 2018. 2 Schools Closed over Satanism Scare. NewsDay Zimbabwe. 14 February 2018. https://www.newsday.co.zw/2018/02/2schools-closed-satanism-scare/.

The Chronicle. 2017. School Girls Collapse in Satanism Scare. 24 March 2017.

http://www.chronicle.co.zw/school-girls-collapse-insatanism-scare/.

Turaki, Yusufu. 1999. Christianity and African Gods: A Method of Theology. Potchefstroom: IRS/PU for CHE.

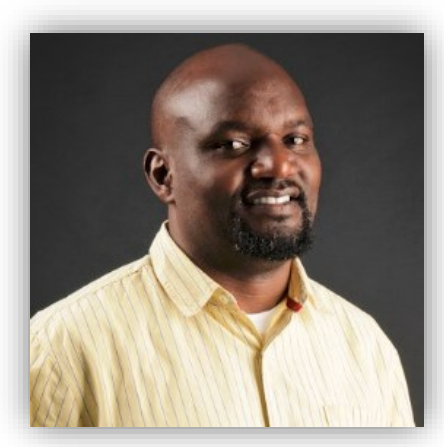

Collium Banda (PhD, Stellenbosch University, South Africa) is a post-doctoral research fellow in the Faculty of Theology at North-West University, South Africa, and adjunct lecturer at Theological College of Zimbabwe in systematic theology and theological ethics. His published articles address the interface of African neo-Pentecostalism with the African sociopolitical and economic realities.

Author email: collium@gmail.com 